\title{
RĪGAS POLITEHNISKĀ INSTITŪTA STUDENTA, PSALMOTĀJA JĀNA JURJENA DZĪVES UN DARBA GAITAS (1866-1915)
}

\section{SERGEJS COJA*}

Rīgas Anniṇmuižas vidusskola

Kopsavilkums. Pareizticīgais igaunis Jāns Jurjens 1888. gadā absolvēja Rīgas Pareizticīgo Garīgo semināru, 1902. gadā - Sanktpēterburgas Garīgo akadēmiju. No 1907. līdz 1910. gadam viṇš studēja Rīgas Politehniskā institūta (RPI) Lauksaimniecības nodậā. 19. gadsimta beigās un 20. gadsimta sākumā J. Jurjens kalpoja pareizticīgajai baznīcai un ticīgajiem kā psalmotājs, tautskolu skolotājs un Rīgas Pareizticīgo Garīgā semināra pedagogs. Viṇš ir vairāku grāmatu un zinātnisko rakstu autors.

Atslēgas vārdi: Rīgas Pareizticīgo Garīgais seminārs, Rīgas Politehniskais institūts, igaunu psalmotājs, Jāns Jurjens.

\section{Mācības, garīgais un pedagoǵiskais darbs}

Rīgas Politehniskajā institūtā 19. gadsimta beigās un 20. gadsimta sākumā studēja dažādu tautību jaunieši, arī igauṇi. Viens no tādiem bija Jāns Jurjens (Jaan Jürjens; Иван Юрьенс; 1866-1915), kurš lielu daļu no savas dzīves pavadīja Rīgā. Te viṇš mācījās un strādāja.

Jāns Jurjens dzimis Vidzemes gubernas Pērnavas apriṇk,a Testamā (Tõstamaa) pagasta Selu muižas (mūsdienās - Seliste) Viggakse sādžas Mardu mājās 1866. gada 7. februārīi nabadzīga pareizticīgā zemnieka Antonija Jurjena un viṇa luterticīgās sievas Rino Jurjenas ǵimenē. Netālu no Jurjenu dzimtas mājām atrodas Seli-Testamā (Seli-Tõstamaa) draudzes Sv. Vasīlija Lielā pareizticīgā baznīca, un tās metriskajā grāmatā tika izdarīts ieraksts par J. Jurjena piedzimšanu un kristīšanu 15. februārī [1].

1 Rakstā datumi minēti pēc Gregora kalendāra jeb jaunā stila.

* Korespondējošais autors.

E-pasts: coja@baltinet.lv 
Ziṇas par Jāna Jurgena bērnību ir skopas. Acīmredzot, viṇš mācījās vietējās pareizticīgās baznīcas draudzes skolā, pēc tam, ap 1878. gadu, kā labākais šìs skolas skolēns iestājās Rìgas Garīgajā skolā un vēlāk mācījās Rīgas Pareizticīgo Garīgajā seminārā. Šāds izglītības ceḷš tajā laikā bija vienīgais, kas deva viṇam iespēju iegūt labu izglītību. Sasniegt savu mērḳi J. Jurjenam palīdzēja viṇa centība un izcilās darbaspējas.

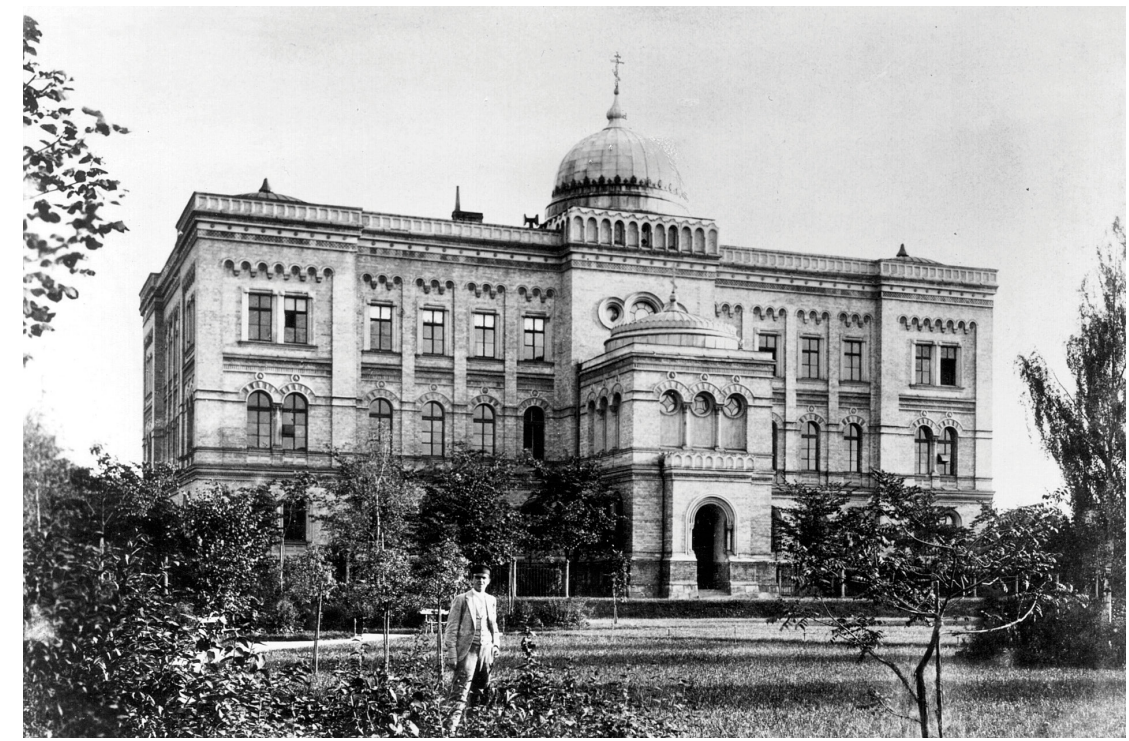

1. attēls. Rīgas Pareizticīgo Garīgā semināra ēka Puškina ielā 9 (tagad - Kronvalda bulv. 9) 20. gadsimta sākumā [2].

1888. gadā J. Jurjens kā pirmais audzēknis pabeidza Rīgas Pareizticīgo Garīgu semināru [3]. Minētā mācību iestāde darbojās no 1851. gada, un tajā pieñēma bērnus, kuri labi pabeidza četrgadīgo Garīgo skolu. Semināra audzēkṇi saṇēma arī vidējo izglītību. Apmācības seminārā ilga sešus gadus. Pirmos četros gados mācību programma bija pielīdzināta protoǵimnāzijas (ǵimnāzija ar atvieglotu programmu) kursam, bet pēdējos divos gados uzsvars tika likts uz teologiskiem priekšmetiem [4].

Pēc semināra pabeigšanas J. Jurjens kḷuva par psalmotāju Vendauas (mūsdienās - Vinnu) Kristus Piedzimšanas pareizticīgo baznīcā. 1889. gada sākumā viṇš tika pārcelts uz Jāṇa un Svētās Trijādības pareizticīgo baznīcu, kas atradās Sāremā salas Eriko muižā. No 1890. līdz 1892. gadam J. Jurjens bija psalmotājs Svētā Nikolaja baznīcā Kuresārē, un tās pareizticīgās draudzes skolā viṇš mācīja krievu valodu un dziedāšanu. Vēlāk, līdz 1894. gadam, viṇš kalpoja par psalmotāju Svētā Jān,a Kristītāja pareizticīgo baznīcā Vīlandē, kur arī strādāja par skolotāju. Par centību un sekmīgu skolotāja darbu Skolu padome viṇam 
izteica pateicību, kas tika publicēta žurnālā «Рижские Епархиальные Ведомости» («Rīgas Eparhijas Ziṇotājs») 1895. gada 1. numurā [5]. 1895. gada augustā J. Jurjens tika iecelts par ticības mācības skolotāju Krenholmas divklasīgā skolā, kas darbojās pie Krenholmas fabrikas Narvā [6]. Šajā skolā viṇš strādāja līdz 1897. gada 12. augustam [7].

Neskatoties uz niecīgajām naudas summām, ko tajā laikā par savu darbu saṇēma psalmotāji un skolotāji, J. Jurjenam izdevās savākt nepieciešamos līdzekḷus un turpināt mācības. 1897. gadā viṇš iestājās Sanktpēterburgas Garīgajā akadēmijā, sākumā - kā brīvklausītājs. 1902. gadā J. Jurjens absolvēja akadēmiju un ieguva teologijas kandidāta grādu ar tiesībām reflektēt teologijas maǵistra grādu bez jauna mutiska pārbaudījuma [8; 9].

J. Jurjens labi pārzināja Bībeli, klasiskās valodas, sanskritu, igauṇu un krievu literatūru, kas vinam deva labas perspektīvas nākotnē. Tomēr vin,š nolēma atgriezties Rīgā, kur bija mācījies, un par salīdzinoši nelielu darba algu sāka strādāt par igauṇu valodas skolotāju Rīgas Pareizticīgo Garīgajā seminārā [10]. Viṇa nekrologā lasām: «.. Savu skolēnu sekmes viṇi $^{2}$ vienmēr atzīmēja ar augstākajām atzīmēm; pret neveiksmēm izturējās ar maksimālu iecietību [11].» Jāatzīmē, ka seminārā ir strādājuši arī citi igauṇi, piemēram, Pēteris Mihkelsons (Peeter Mihkelson; 18421914) [12; 13]. Viṇi strādāja mācību iestādē, Rīgas Pareizticīgo Garīgajā seminārā, kas sniedza labu izglītību, un 20. gadsimta sākums tai bija ḷoti auglīgs laiks [14].

1907. gadā J. Jurjens iestājās Rīgas Politehniskā institūta Lauksaimniecības nodal̦ā. Domājams, ka viṇš gribēja iegūt agronoma diplomu, lai nodarbotos arī ar lauksaimniecību. Tajā laikā liela daḷa igauṇu bija zemnieki, arī J. Jurjena vecāki. Diplomētiem inženieriem bija izredzes nopelnīt vairāk nekā skolotājiem. Diemžēl RPI diplomu viņš neieguva, jo 1910. gada janvārī J. Jurjens studiju naudu nesamaksāja un no augstskolas izstājās [15].

Par nopelniem sabiedrības labā 1908. gadā J. Jurjens tika apbalvots ar trešās šķiras Svētā Staṇislava ordeni. Tajā pašā laikā viṇam pēc Krievijas impērijas rangu tabulas bija koledžas asesora pakāpe [16].

Igaunis Jāns Jurjens nebija precējies un dz̄ivoja viens. Pēdējos mūža gados viṇš slimoja ar tuberkulozi, kas saīsināja viṇa dzīvi [17]. J. Jurjens devās mūžības cel̦ā 1915. gada 9. februārī. Nāves dienā nelaiksis tika atnests uz Rīgas Pareizticīgo Garīgā semināra telpām Rīgā, Puškina ielā (tagad - Kronvalda bulvāris) 9 un novietots aktu zālē. Panihīdu veica Rīgas un Jelgavas arhibīskaps Jānis (Ivans Smirnovs; И. Смирнов; 1844-1919; pārvaldīja Rīgas eparhiju no 1910. līdz 1917. gadam) [18]. Apbedīšana notika 11. februārī Rīgas Pokrova kapos. Bēru liturǵiju vadīja semināra rektors virspriesteris Aleksejs Lebedevs (А. Лебедев;

2 J. Jurjens un viṇa kolēgis P. Mihkelsons. 
1856-1918). Tā laika laikrakstos un žurnālos J. Jurjena bērēm veltìtajos rakstos bija teikts, ka semināristi mīlēja savu skolotāju un pie apbedīšanas vinu acis aizmigloja asaras. Nelaiķa kolēgis virspriesteris Vladimirs Pliss (В. Плисс; 1862-1927) pie apbedīšanas nolasīja I. Nikitina dzejas «Вырыта заступом яма глубокая» («Izrakta ar lāpstu bedre dziḷı») rindas un raksturoja aizgājēja darbību ar sirsnīgiem vārdiem, uzsverot, ka J. Jurjena dzīve bija cenšanās dot labumu viṇa iemīḷotajam semināram un pareizticīgajiem igauṇiem [18]. Līdz mūsdienām J. Jurjena kaps Rīgas Pokrova kapos nav saglabājies [19].

\section{Jāna Jurjena raksti un grāmatas}

Mūža pēdējos gados J. Jurjens uzrakstīja vairākus rakstus un grāmatas, galvenokārt veltītus Baltijas vēsturei, kas publicēti krievu valodā. 1904. gadā iznāca J. Jurjena darbs «Древнейшая Ливонская хроника» («Vissenākā Livonijas hronika») [20], kas veltīta 13. gadsimta sākumā uzrakstītajai Indriķa Livonijas hronikai, kurā atspoguḷoti notikumi Latvijas un Igaunijas teritorijās 12. gadsimta beigās un 13. gadsimta sākumā [21]. Jāns Jurjens aizstāvēja tēzi, ka hronikā minēto priesteri Indriķ̣i, kuru lielākā daḷa zinātnieku uzskata par šĩ teksta autoru, par tādu nevar saukt [22]. J. Jurjens uzskatīja, ka vēsturnieku apgalvojumu pamatā ir tikai minējumi. Tā priestera Indriḳa draudzes atrašanās tālu no Rīgas liecina par viṇa zemo sociālo stāvokli un par to, ka viṇam nav bijusi laba izglìtība, kas ir nepieciešama, lai uzrakstītu tāda līmeņa hroniku. Teksta autors, bez šaubām, ir garīdznieks, bet noteikti augstāka līmeṇa nekā draudzes mācītājs. Teologs J. Jurjens rakstīja, ka, iespējams, hronikas autors bijis vācietis, jo viṇš hronikas tekstā vismaz divas reizes sevi identificē ar vāciešiem [23]. Daži viṇa argumenti ir pretrunīgi un neko nepierāda. Piemēram, viṇa apgalvojums, ka no Rīgas draudzes tālumā dzīvojošam mācītājam nevarēja būt laba līmen,a izglīīiba.

\section{ДРЕВНЬЙШАЯ}

\section{ЛИВОНСКАЯ ХРОНИКА.}

Иe. ЮPЬEHCЪ.
2. attēls. J. Jurjena grāmatas «Древнейшая Ливонская хроника» («Vissenākā Livonijas hronika») vāks (1904) [20]. 
1910. gadā tika publicēta J. Jurjena brošūra «Прибалтийский край под русской властью: к 200 летн. юбилею присоединения Прибалтийского края к Русской державе: (4 июля 1710 - 4 июля 1910 2.)» («Baltija zem Krievijas iespaida un valdības. Baltijas pie Krievijas pievienošanas 200 gadu jubilejai par piemiṇu. (1710. gada 4. jūlijs 1910. gada 4. jūlijs»)] [24]. Šis J. Jurjena darbs tika iztulkots un izdots arī latviski [25]. Tulkotāji parakstījušies ar J. un K. Iespējams, ka viens no tulkotājiem ir advokāts, laikrakstu un žurnālu līdzstrādnieks Jānis Pelūde (1873-1911), kura pseidonīms bija «J». Ar pseidonīmu «K» darbojās dzejnieks Kārlis Eliass (1899-1985), kurš darba tulkošanas laikā bija apmēram 10-11 gadu vecs skolnieks [26], tāpēc jāšaubās, vai viṇš ir viens no tulkotājiem. Lai gan vietējā latviešu prese atzina tulkojumu par «skolniecisku» [27], patiesos tulkotājus nav norādījuši arī bibliotekāri, kuri veic iespieddarbu kataloǵizāciju un informācijas apstrādi. Brošūras izdošana bija pielāgota Igaunijas un Vidzemes teritorijas iekarošanas un pievienošanas Krievijas impērijai 200 gadu jubilejai. Darba oficiālais raksturs saskatāms jau tā sākumā. J. Jurjens aizstāvēja tēzi, ka Baltijas zemes piederēja Krievijai vēl pirms vāciešu parādīšanās šeit un cars Pēteris I tikai 18. gadsimta sākumā tās atgrieza atpakal̦. Darbā ir arī sīks vēsturisks apskats par 12.-13. gadsimta notikumiem. Tālāk uzmanība koncentrēta uz 1710. gadu un 19. gadsimta 40. gadiem, kas saistīti ar pareizticības izplatīšanos un vietējo iedzīvotāju pāriešanu pareizticībā [28]. Minētajā brošūrā visur slavēta Krievijas impērija un krievu tauta, un tā tapusi laikā, kad Baltijas guberṇas bija pakḷautas rusifikācijai. Zinātniskas vērtības minētajam darbam nav, jo tas kalpoja tikai tā laika Krievijas varas politiskajai propagandai. Acīmredzot J. Jurjenam bija pasūtījums sarakstīt šāda veida sacerējumu, no kura atteikties viṇš nevarēja, jo kā Rīgas Pareizticīgo Garīgā semināra pedagogs vinšs bija atkarīgs no savas cariskās priekšniecības. Diemžēl šĩ brošūra nesniedz atbildi par viña paša attieksmi pret minētajiem notikumiem. Kritikas gadījumā cariskā cenzūra nebūtu aț̦āvusi to iespiest.

1912. gadā iznāca J. Jurjena grāmata «Эстская грамматика: со статьями для чтения и построчнымъ словарем» («Igauñu gramatika ar rakstiem lasīšanai un zemteksta vārdnīcu») [29]. Tā ir īsa igauṇu valodas mācību grāmata, kas sastādīta ar krievu valodas ievadu un paskaidrojumiem. Tajā ir gan igauṇu valodas gramatika, gan materiāli lasīšanai un neliela igauṇu-krievu vārdnīca. Tajā laikā trūka šāda veida izdevumu, tāpēc autors sagatavoja minēto grāmatu.

Pēdējais J. Jurjena darbs «Вопрос о ливонской дани» («Jautājums par Livonijas nodevām») tika nopublicēts 1913. gadā Varšavā. Tas veltīts jautājumam par nodevām, ko Livonijas zemes maksāja krievu valdniekiem. Šì temata aktualitāte, kā uzsvēra autors, bija saistīta ar jautājuma aktualizēšanu par Krievijas tiesībām uz Baltijas zemēm. Tās kḷuva par 
vienu no iemesliem Livonijas kara uzsākšanai. Darbā stāstīts par vairākiem līgumiem, kas noslēgti dažādos laikos starp Livonijas valdniekiem un Krievzemi un kuros bija pieminētas nodevas par labu pēdējai. Par reālajiem nodevu apjomiem ir grūti spriest. Krievi šīs tiesības pamatoja uz vecajām nodevām, ko dal̦a vietējo iedzīvotāju maksāja par labu krievu kṇaziem vēl pirms vāciešu ierašanās Baltijas zemēs. Par Ivana IV (Иоанн IV; Иван Грозный; 1530-1584) pretenzijām uz šīm nodevām J. Jurjens rakstīja, ka tajā laikā tiesības prasīt maksāt kaut ko sev par labu pamatojās vienīgi uz stiprākā tiesībām [30]. Stiprāka bija lielā Krievija, tāpēc Livonijai bija jāmaksā.

Igaunis Jāns Jurjens nodzīvoja 49 gadus. Neskatoties uz trūcīgiem materiālajiem apstākḷiem un slikto veselību, viṇam izdevās iegūt labu izglītību, kalpot savai tautai kā pareizticīgajam psalmotājam, tautskolu skolotājam un Rīgas Pareizticīgo Garīgā pedagogam, uzrakstīt vairākus rakstus un grāmatas.

\section{AVOTU UN LITERATŪRAS SARAKSTS}

[1] Estonian arhives in Tartu (EAA) 1973. 1. 478. Sv. Vasīlija Lielā draudzes Seli-Testamaa pareizticīgās baznīcas metrisku grāmata par 1865.-1868. g.

[2] Rīgas Pareizticīgo Garīgā semināra ēka Puškina ielā 9 (tagad - Kronvalda bulv. 9) 20. gadsimta sākumā. Foto no D. Trubeckoja personīgā arhīva.

[3] Razrjadnyj spisok vospitannikov Rizhskoj duhovnoj seminarii, sostavlennyj v pedagogicheskom sobranii pravlenija 20-21 ijunja $1888 \mathrm{~g}$. posle byvshih ispytanij. Rizhskie Eparhialnye Vedomosti, 1888, Nr. 13-14, s. 393.

[4] Vičs, A. Latviešu skolu vēsture. Piektā grāmata. Laikmets no 1905.-1915. Rīga, R.L.B. Derīgu grāmatu nodaḷas apgāds, 1940, 328.-329. lpp.

[5] Ot uchilishhnogo soveta. Rizhskie Eparhialnye Vedomosti, 1895, Nr 1, s. 11.

[6] Latvijas Valsts vēstures arhīvs (LVVA) 4754. f., 2. apr., 147. l., 992. lp.; 167.l., 1487.-1488. lpp. Rīgas eparhijas klēru raksti par 1894. gadu.

[7] EAA 260.1.467; J. Jurjena personāllieta, 1895.-1897.g.

[8] Ivan Antonovich Jurjens. Rizhskie Eparhialnye Vedomosti, 1915, Nr. 4, s.126.

[9] Prepodavatel rizhskoj duhovnoj seminarii Ivan Antonovich Jurjens. Rizhskij Vestnik, 1915, Nr. 22, s. 1.

[10] LVVA, 7416. f., 1. apr., 7. 1., 2., 26., 60.lp.

[11] Ivan Antonovich Jurjens. Rizhskie Eparhialnye Vedomosti, 1915, Nr. 4, s. 124.

[12] Nekrolog. Pohorony prepodavatelja P. M. Mihkelsona. Rizhskie Eparhialnye Vedomosti, 1914, Nr. 21, S. 629-631.

[13] Vidjakina, S. A., Kovalchuk, S. N. (sost.). Pokrovskoe kladbishhe. Slava I zabvenie.-Sbornik statej. Riga: Multicentrs, 2004, s. 71. 
[14] Vičs, A. Latviešu skolu vēsture. Piektā grāmata. Laikmets no 1905.-1915. Rīga, R.L.B. Derīgu grāmatu nodaḷas apgāds, 1940, 320.-322. lpp.

[15] LVVA 7175. f., 1. apr., 1908. l., 166. lp. RPI studentu reǵistrs.

[16] Eparhialnye izvestija. Vysochajshie nagrady. Rizhskie Eparhialnye Vedomosti, 1908, Nr. 10, s. 376.

[17] LVVA, 7416. f., 1. apr., 1. l., 1.-2. lp., Rīgas Pareizticīgo Garīgā semināra valdes sēdes protokoli.

[18] Gorodskoj dnevnik. Pohorony I. A. Jurjensa. Rizhskij Vestnik, 1915, Nr. 24, s. 3.

[19] Vidjakina S. A., Kovalchuk S. N. (sost.). Pokrovskoe kladbishhe. Slava I zabvenie.-Sbornik statej. Riga: Multicentrs, 2004, s. 95.

[20] Jurjens I. A. Drevnejshaja Livonskaja hronika. Otdelnyj ottisk iz Zapiski imperatorskogo russkogo arheologicheskogo obshhestva. Tom V, vyp. 2. Sanktpeterburg, 1904, 17 s.

[21] Coja, S. Henriha / Indriķa chronicon Livoniae autora identitātes problēma Krievijas historiogrāfijā. Latvijas Vēstures Institūta Žurnāls, 2011, Nr. 3, 72. lpp.

[22] Coja, S. Die Frage der Herkunft des Chronisten Henrich von Lettland in der russischen Historiografie. In: Forschungen zur baltischen Geschichte. Band 9. Tartu: Akadeemiline ajalooselts, 2014, S. 19-20.

[23] Jurjens I. A. Drevnejshaja Livonskaja hronika. Otdelnyj ottisk iz Zapiski imperatorskogo russkogo arheologicheskogo obshhestva.Tom V, vyp. 2. Sanktpeterburg, 1904, 2., 7., 11., 12., 14. str.

[24] Jurjens I. A. Pribaltijskij kraj pod russkoj vlastju. K 200-letn. jubileju prisoedinenija Pribaltijskogo kraja k russkoj derzhave (4 ijulja 1710-4 ijulja1910 goda. Riga: tipografija G. Gemel i Ko, 1910, 24 s.

[25] Jurjens J. Baltija zem Krievijas iespaida un valdības. Baltijas pie Krievijas pievienošanas 200-gadu jubilejai par piemiṇu. Rīga: Rīgas Pētera-Pāvila brālības izdevums, 1910, 24 lpp.

[26] Latviešu rakstniecība biogrāfijās. Rīga: Zinātne, 2003, 697., 698. lpp.

[27] Grāmatu plaukts. Dzimtenes Vēstnesis, 1910. Nr. 157, 3. lpp.

[28] Jurjens J. Baltija zem Krievijas iespaida un valdības. Baltijas pie Krievijas pievienošanas 200-gadu jubilejai par piemiṇu. Rīga: Rīgas Pētera-Pāvila brālības izdevums, 1910, 5., 20., 22.-23. lpp.

[29] Jurjens I. A. Estskaja grammatika: so statjami dlja chtenija i postrochnym slovarem. Riga: Tip. T. Vilks i E. Shkinkis, 1912, 96 s.

[30] Jurjens I. A. Vopros o Livonskoj dani. Varshava: Tip. Varshavskogo uchebnogo okruga, 1913, s. 1.-6, 52.-53., 39., 41., 57. lpp.
Sergejs Coja

Rīgas Politehniskā institūta studenta, psalmotāja

Jāna Jurjena

dzīves un darba

gaitas

(1866-1915) 


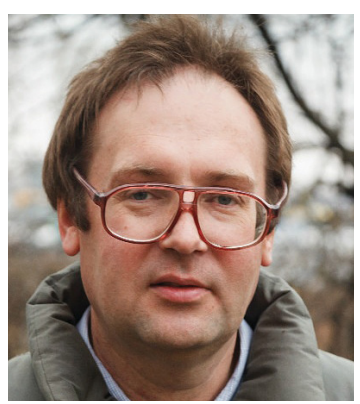

SERGEJS COJA, Mg. hist., is a teacher at the Riga Anniņmuiža Secondary School (since 2013). His main academic interests are the history of pedagogy, and history of national minorities in Latvia.

Address: 50 Tapešu Street, Flat 10, Riga, LV-1083, Latvia

Phone: +37129105468

E-mail:coja@baltinet.lv

Sergejs Coja

The life and work of the student of the Riga Polytechnic Institute, psalmist Jaan Jürjens (1866-1915)

Jaan Jürjens was an Estonian of Russian Orthodox faith. He graduated from the Riga Orthodox Theological Seminary in 1888 and from St. Petersburg Orthodox Theological Academy in 1902. From 1907 to 1910, he studied at the Department of Agriculture of Riga Polytechnic Institute. During the late 19th and early 20th centuries, he served the Russian Orthodox Church and fellow humans as churchwarden, elementary school teacher and professor of Orthodox Theological Seminary. Jaan Jürjens is an author of several published books and scientific papers.

Keywords: Riga Orthodox Theological Seminary, Riga Polytechnic Institute, Estonian psalmist, Jaan Jürjens.

Сергей Цоя

Жизненный путь и трудовая деятельность студента Рижского политехнического института, псаломщика Яана Юрьенса (1866-1915)

Иван (Яан) Антонович Юрьенс - православный эстонец, обучался в 1907-1910 годах на Сельскохозяйственном отделении Рижского политехнического института. В 1888 году он окончил Рижскую православную духовную семинарию, а в 1902 году Санкт-Петербургскую духовную академию. В конце XIX - начале XX служил Православной церкви и простым людям, учителем народных школ, преподавателем духовной семинарии. И. А. Юрьенс являлся автором нескольких книг и научных статей.

Ключевые слова: Рижская православная духовная семинария, Рижский политехнический институт, Иван Юрьенс. 